\title{
Meio- and macrofauna in the marine area of the Monte St. Bartolo Natural Park (Central Adriatic Sea, Italy)
}

\author{
FEDERICA SEMPRUCCI ${ }^{1}$, FABRIZIO FRONTALINI ${ }^{1}$, \\ ANABELLA COVAZZI-HARRIAGUE ${ }^{2}$, RODOLFO COCCIONI ${ }^{1}$ and MARIA BALSAMO ${ }^{1}$ \\ ${ }^{1}$ Dipartimento di Scienze della Terra, della Vita e dell'Ambiente (DiSTeVA), Università di Urbino, loc. Crocicchia, \\ 61029 Urbino, Italy. E-mail: federica.semprucci@ uniurb.it \\ ${ }^{2}$ Dipartimento per lo Studio del Territorio e delle sue Risorse (Dip.Te.Ris.), Università di Genova, C.so Europa 26, \\ 16132 Genova, Italy.
}

\begin{abstract}
SUMMARY: This paper presents an integrated investigation of benthic foraminiferal, meiofaunal and macrofaunal assemblages that was carried out in front of the marine area of the Monte St. Bartolo Regional Natural Park (Adriatic Sea, Italy). Although this area is not yet subject to conservation plans, an overall good quality status of its benthic assemblages was documented. In particular, the assemblages were somewhat diversified and generally minimally to moderately affected by anthropogenic activities. Both the foraminifera and macrofauna seemed to be primarily influenced by variations in the habitat's features, whereas significant changes in the meiofaunal assemblage were related more to trophic supply fluctuations. These data suggest the potential vulnerability of this area and highlight the importance of defining and applying an appropriate integrated zone management plan.
\end{abstract}

Keywords: benthic community, biodiversity, Monte St. Bartolo Regional Natural Park, Adriatic Sea.

RESUMEN: Meio- y macrofauna en el Área marina del Parque Natural del Monte San Bartolo (mar Adriático central, ITALIA). - En este trabajo se presentan los resultados de una investigación integrada sobre las comunidades de foraminíferos bentónicos, de meiofauna y de macrofauna efectuada en el área marina ubicada frente al Parque Natural Regional del Monte San Bartolo (mar Adriático, Italia). A pesar de que esta área no está aún sujeta a planes de conservación, se ha observado un buen estado en sus comunidades bentónicas. En particular, ellas son relativamente bien diversificadas y generalmente las actividades de origen antrópico las afectan en grado mínimo o moderado. Foraminíferos y macrofauna parecen estar influenciadas sobre todo por los cambios de la fisonomía del habitat, mientras que los cambios observados en la meiofauna están principalmente relacionados con las fluctuaciones del suministro trófico. Estos datos sugieren la posible vulnerabilidad de esta area y destacan la importancia de definir y aplicar un plan adecuado de gestión integrada de la zona.

Palabras clave: comunidades bentónicas, biodiversidad, Parque del Monte San Bartolo, mar Adriático.

\section{INTRODUCTION}

Coastal systems are one of the most sensitive and vulnerable marine areas, where economic activities are concentrated and natural resources are highly compromised. In particular, the coastline is an important source of nutrients and pollutants for neighbouring open seas (Moodley et al. 1998, Albertelli et al. 1999, Danovaro et al. 2000, Lee et al. 2001, Frontalini and Coccioni 2008, 2011, Semprucci et al. 2010a).

Benthic communities in particular are an important source of information that can be utilized to investigate and characterize the habitat in which they live. Indeed, since macrobenthos and meiobenthos have different ecological roles in marine ecosystems (Coull and Bell 1979, Coull and Palmer 1984), they may respond to disturbances at different spatial and temporal levels (Bell 1980). Furthermore, data on these organisms might also reveal different, but complementary, elements of the factors that structure the benthic ecosystem, and can thus be considered in an assessment of the ecological status of the seafloor. 
The Mediterranean Sea, which has high levels of endemism in its coastal zones, is a valuable location for such a study. It is characterized not only by high species diversity (just lower than that of tropical areas), but also by extremely diverse adaptive strategies for determining high levels of functional diversity (Coll, 2010). Moreover, well-documented habitat destruction, over-fishing, water pollution and eutrophication, species introduction, and climatic changes make the Mediterranean a key area for studying the influence of natural and anthropogenic changes on biodiversity (Danovaro and Pusceddu 2007). In the Adriatic Sea, which is a closed basin, these changes may even be enhanced, leading to its greater vulnerability (Balsamo et al. 2010). Protection and management programmes are required to conserve the coastal areas and their communities, with a special focus on the most sensitive and vulnerable environments. Marine Protected Areas (MPAs) are effective tools with which to achieve national and international conservation plans that help to reduce biodiversity loss (Sandulli et al. 2010, 2011). Indeed, three MPAs have been established in the Italian part of the Adriatic Sea, and another three will be created shortly. Furthermore, there are many protected coastal areas of high naturalistic and conservationist value, one of which is the Monte San Bartolo Regional Natural Park (northern Marche region). The growing need for a network of coastal management systems and MPAs requires detailed biodiversity assessments at different taxonomic levels, as well as studies with which to evaluate the real ecological state and quality of these areas. Integrated investigations of marine benthic communities have enabled us to carry out comprehensive studies on some taxa and their responses to environmental changes. It must, however, be emphasized that very few synoptic approaches have been performed up to now, especially in the Mediterranean basin (see Semprucci et al. 2010a for details).

In this context, a study using an integrated approach has been commenced along the Monte St. Bartolo coast, which is a valuable but vulnerable area that has not yet been subject to any conservation plans. The aim of this investigation is to document the composition and biodiversity of the entire benthic community (foraminifera, meiofauna and macrofauna) in this poorly known coastal area of the Adriatic Sea and to assess the spatial distribution and temporal variations of its benthic communities.

\section{MATERIALS AND METHODS}

\section{Study area}

The study area is located along the coast of the northern Marche region (Italy), and extends from Gabicce to Fano (Fig. 1). Part of the area (GabiccePesaro) is a cliff, the first rocky shore to interrupt the monotonous continuity of sandy beaches on the Italian side of the Adriatic Sea, south of Monfalcone (Trieste)
(Colantoni et al. 2004). It is also the seaward limit of the Monte San Bartolo Regional Natural Park, which was created in 1997 to protect an area of great naturalistic importance, since it lies along a main bird migratory route, includes the wintering habitats of many bird species, and also plays host to some rare plant species. The coastal strip is still poorly known, though it is characterized by important hot-spots of zoobenthic biodiversity and a few seagrass meadows (Coccioni 2003, Balsamo et al. 2011). Seawards, fine and silty sands cover the seafloor, merging into an offshore mud belt about $3 \mathrm{~km}$ from the coastline (see Colantoni et al. 2004 and references therein). Although the area is characterized by lower primary productivity than the North Adriatic Sea (Zavatarelli et al. 2000), the contribution of local Apennine rivers and the nutrient-enriched coastal current coming from the northern basin enhance its nutrient availability (Artegiani et al. 1997). The main pollution sources in the area are touristrelated activities, which discharge untreated sewage. The area is characterized by the outflow of three rivers, the Tavollo, Foglia and Metauro, along with several smaller streams (e.g. Arzilla and Genica) (Fig. 1). The River Foglia is the greatest source of pollution, because it carries wastewater from urban and industrial areas and livestock farms (Gaudiano et al. 1994). Pesaro and Gabicce, with a population of $\sim 750$ and 1250 inhabitants per $\mathrm{km}^{2}$, are the main cities closest to the Monte San Bartolo Natural Park.

\section{Sampling sites}

Six sites were selected along this coastal area from north to south: Tavollo (T), Vallugola (V), Fiorenzuola (F), Brisighella (B), Foglia (FO) and Metauro (M). Transects orthogonal to the sea coast were laid at each site, while two stations at $500 \mathrm{~m}$ (Station 1, depth of $\sim 5 \mathrm{~m}$ ) and $3000 \mathrm{~m}$ (Station 4, depth of $\sim 13 \mathrm{~m}$ ) were sampled along each transect (Fig. 1). The sites were sampled in collaboration with ARPAM (the Regional Environmental Agency for the Marche region) over the course of three seasons in 2002: spring (SP), summer (S) and autumn (A), and each sample was labelled according to its distance from the coast (1 to 4), the transect it had come from (T, V, F, B, FO and M), and the sampling season (SP, S and A). Sediment samples were collected using a Van Veen Grab $(400 \times 220 \mathrm{~mm})$ and then sub-sampled for analyses of total organic matter content (TOM), grain size, foraminifera, meiofauna and macrofauna.

\section{Environmental parameters}

The TOM content was determined gravimetrically after loss on ignition (Buchanan and Kain 1971). The sediment samples were initially dried at $60^{\circ} \mathrm{C}$ for six hours and weighed in a Scaltec SBC21 (accuracy 0.1 $\mathrm{mg}$ ) to obtain their dry weight. The sediments were then calcined in a muffle furnace $\left(550^{\circ} \mathrm{C}\right.$ for $\left.4 \mathrm{~h}\right)$ and 


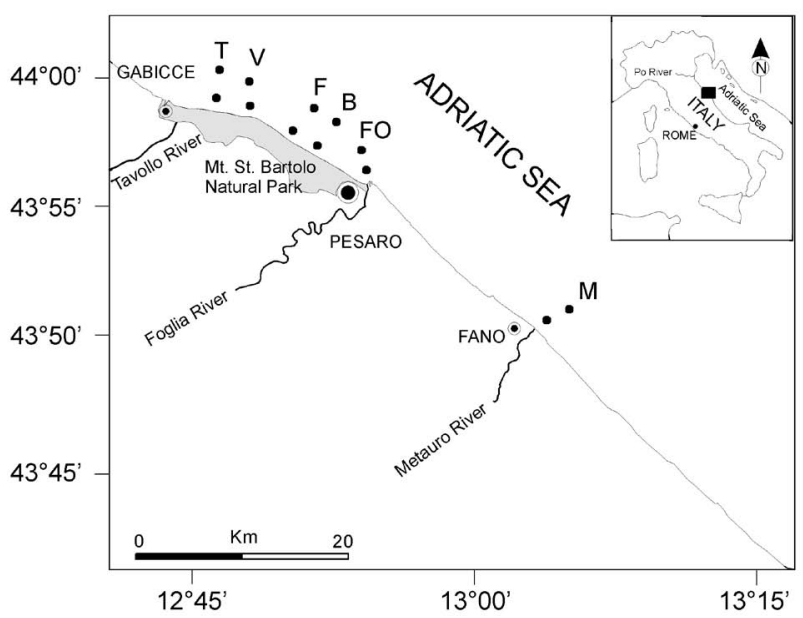

FIG. 1. - Location map of the study area with sampling stations.

weighed again to determine the ash weight (inorganic fraction). Then, the organic fraction content was calculated by subtracting the ash weight from the total weight. Grain size analysis was performed by separating the coarse fraction (sand) from the mud fraction (pelite) by washing. The sandy fraction was then analyzed by dry-sieving, while a sedigraph (Sedigraph 5200 , Micrometric) was used for the pelite fraction $(<63 \mu \mathrm{m})$. The samples for the grain size analysis were collected during each sampling session, as reported by Colantoni et al. (2003).

\section{Benthic community analysis}

\section{Benthic foraminifera}

A constant volume of $50 \mathrm{~cm}^{3}$ of sediment was taken from the upper $2 \mathrm{~cm}$ and immediately stained with buffered Rose Bengal dye (2 $\mathrm{g}$ of Rose Bengal in $1000 \mathrm{ml}$ of ethyl alcohol). The samples were treated with standard techniques, largely following the work of Frontalini and Coccioni (2008) and Frontalini et al. (2009, 2010). Foraminiferal density (FD; defined as the total number of living specimens per gram of dried sediment), species richness (S), infaunal percentages and the foraminiferal abnormality index (FAI) were calculated for all of the samples. The infaunal taxa were allocated mainly following Murray (2006).

\section{Meiofauna}

Three cores (surface area $6 \mathrm{~cm}^{2}$ ) were taken down to a sediment depth of $9 \mathrm{~cm}$. The sediment was treated with $7 \%$ of $\mathrm{MgCl}_{2}$, then fixed with $4 \%$ neutralized formalin in seawater and stained with Rose Bengal. The samples were then sieved through 45- to 500- $\mu$ m mesh nets. The residual fraction obtained in this way was centrifuged three times with Ludox HS 30 colloidal silica (density $1.18 \mathrm{~g} \mathrm{~cm}^{-3}$ ) for specimen extraction purposes (McIntyre and Warwick 1984). The meiofauna were counted and identified at the major taxa level, and their density was standardized as abundance $10 \mathrm{~cm}^{-2}$. In order to describe the meiofaunal assemblage, the total meiofaunal density (TMED), Shannon H' and Pielou J' indices, which were $\log _{2}$-transformed, were calculated.

\section{Macrofauna}

The sediments were sampled using a manual corer (surface area $102 \mathrm{~cm}^{2}$ ) (Gunther 1996; Neira et al. 2011), carefully washed through a $0.5-\mathrm{mm}$ mesh sieve, and treated with $10 \%$ neutralized formalin in seawater. The specimens were taxonomically identified, mainly to species level, for mollusks, echinoderms and crustaceans, and the macrofaunal density was standardized as abundance ind. $\mathrm{m}^{-2}$. In order to obtain the biomass value, the organisms were dried at $60^{\circ} \mathrm{C}$ for $24 \mathrm{~h}$ and weighed, while the mollusks and echinoderms were treated with $30 \% \mathrm{HCl}$ before drying. The biomass was expressed as $\mathrm{mg} \mathrm{m}^{-2}$ of the DW (dry weight). The Shannon H' and Pielou J' indices, both of which were $\log _{2}$-transformed, were calculated only for crustaceans, mollusks and echinoderms.

\section{Statistical analysis}

A data matrix was created using the sediment characteristics (TOM, percentages of gravel, sand and mud); foraminiferal density (FD) and species richness (S); the main meiofaunal indices (TMED, J' and $\mathrm{H}^{\prime}$ ) and taxa abundance (Nematoda, Copepoda, Platyhelminthes, Polychaeta, Oligochaeta and Others); and the macrofaunal indices (TMAD, TMAB, J' and H') and taxa abundance and biomass (Mollusca, Annelida, Crustacea, Echinodermata and Others).

Non-metric multi-dimensional scaling (nMDS) ordinations derived from Bray-Curtis similarity matrices (fourth-root transformed) were used to view spatial and temporal differences in the structures of each benthic assemblage. Furthermore, the formal significance of the differences in the benthic assemblages was tested by means of the analysis of similarity (two-way crossed ANOSIM, depth $\times$ season). All of the multivariate analyses were performed with the PRIMER software, v.5 (Clarke and Gorley 2001, Clarke and Warwick 2001).

In order to elucidate the relationships between biotic and abiotic variables, $\log (1+\mathrm{x})$ transformed, a Pearson correlation analysis was conducted using the Statistica 6.0 program. The Abundance Biomass Comparison (ABC) curves proposed by Warwick (1986) for detecting pollution effects on marine zoobenthic communities were created using the PRIMER 5.0 software package. The numerical distribution of individuals among species and the distribution of biomass among species exhibit a differential response to disturbance. This difference is highlighted by the dominance of r-selected (opportunistic) species in disturbed areas, which is in contrast to the competitive dominance of the $\mathrm{k}$-selected (conservative) species in communities that are in equilibrium and have a relatively stable en- 
TABLE 1. - Total Organic Matter (TOM) and grain-size data of collected sediments. SP, spring; S, summer; A, autumn.

\begin{tabular}{lccccccc}
\hline & & Mean & Stns 1 & Stns 4 & SP & S & A \\
\hline TOM & $(\mathrm{mg} / \mathrm{g})$ & 44.7 & 28.0 & 61.5 & 41.3 & 42.9 & 50.1 \\
gravel & $(\%)$ & 0.9 & 0.4 & 1.3 & 0.5 & 1.1 & 1.0 \\
sand & $(\%)$ & 56.8 & 93.8 & 19.8 & 56.4 & 59.8 & 54.2 \\
mud & $(\%)$ & 42.3 & 5.7 & 78.9 & 43.1 & 39.1 & 44.7 \\
\hline
\end{tabular}

vironment. Accordingly, when the biomass curve lies above the abundance curve, the macrofauna community is dominated by k-strategist species and is stable (the abundance has greater diversity than the biomass). In contrast, when the cumulative biomass curve intersects or overlaps with the cumulative abundance curve, the macrofauna community is disturbed and the level of stability reduced.

\section{RESULTS}

\section{Environmental parameters}

The TOM exhibited a clear distributional pattern, with higher values seawards. The mean value of Stations $1\left(28 \mathrm{mg} \mathrm{g}^{-1}\right)$ was remarkably lower than the mean value $\left(61.5 \mathrm{mg} \mathrm{g}^{-1}\right)$ of Stations 4 . The highest TOM value ( $86.2 \mathrm{mg} \mathrm{g}^{-1}$ ) was found at B4S, whereas the lowest (17.9 $\left.\mathrm{mg} \mathrm{g}^{-1}\right)$ was at M1SP (Table 1). Moreover, the mean spring and summer TOM values were lower than the autumn ones. Most of the sediments were fine sands and mud. The coarser fraction ( $>2 \mathrm{~mm}$ ), when present, was made up of gravel, which was only a minor component $(<0.9 \%$, on average) of the sediments. A main bipartition was recognized between the sandy and muddy bottoms. The stations closer to the seacoast were dominated by sands, and the mud fraction was only a minor component ( $93.8 \%$ of sand and $\sim 5.7 \%$ of mud, on average). On the other hand, the opposite composition was found at Stations $4(\sim 19.8 \%$ of sand and $\sim 78.9 \%$ of mud, on average). No marked changes were identified between the different sampling seasons in terms of their grain-size components. The correlation matrix highlighted a significantly positive coefficient of correlations (0.92) between TOM and mud, and a strongly negative coefficient with sand (-0.76) (Supplementary Material, Appendix 1).

\section{The benthic community structure}

\section{Benthic foraminifera}

Most of the studied samples contained abundant and well-preserved living benthic foraminifera, which were generally associated with common fragments of mollusks, ostracods, bryozoans and annelids. A total of 21 benthic foraminiferal species (19 calcareous and two agglutinated) belonging to 14 genera were identified in the living assemblage. The living assemblages were largely dominated by infaunal
TABLE 2. - Relative abundances of benthic foraminiferal taxa and assemblage parameters. SP, spring; S, summer; A, autumn; FD, foraminiferal density; $\mathrm{S}$, species richness; FAI, foraminiferal abnormality index.

\begin{tabular}{lcccccc}
\hline Foraminifera & Mean & Stns 1 & Stns 4 & SP & S & A \\
\hline Ammonia parkinsoniana & 46.3 & 41.4 & 51.3 & 34.6 & 51.9 & 52.5 \\
Ammonia tepida & 13.4 & 15.5 & 11.2 & 18.3 & 13.3 & 8.5 \\
Aubignyna perlucida & 4.9 & 3.4 & 6.4 & 6.3 & 4.9 & 3.5 \\
Bolivina seminuda & 5.0 & 2.8 & 7.2 & 5.4 & 5.1 & 4.4 \\
Bolivina spathulata & 0.1 & 0.0 & 0.1 & 0.2 & 0.0 & 0.0 \\
Bolivina striatula & 1.7 & 1.8 & 1.5 & 2.4 & 1.1 & 1.5 \\
Bulimina elongata & 0.7 & 0.4 & 1.0 & 0.4 & 1.2 & 0.6 \\
Bulimina marginata & 0.6 & 0.5 & 0.6 & 0.7 & 0.1 & 0.9 \\
Buliminella elegantissima & 2.0 & 2.2 & 1.9 & 3.4 & 1.1 & 1.6 \\
Cribroelphidium oceanensis & 0.2 & 0.0 & 0.3 & 0.3 & 0.0 & 0.2 \\
Eggerelloides scaber & 12.6 & 16.3 & 9.0 & 6.3 & 14.9 & 16.7 \\
Elphidium advenum & 0.0 & 0.0 & 0.0 & 0.0 & 0.0 & 0.0 \\
Elphidium macellum & 0.0 & 0.0 & 0.1 & 0.0 & 0.0 & 0.1 \\
Elphidium jenseni & 0.3 & 0.0 & 0.6 & 0.0 & 0.8 & 0.0 \\
Elphidium crispum & 0.1 & 0.0 & 0.2 & 0.2 & 0.0 & 0.1 \\
Hopkinsina pacifica & 2.0 & 1.8 & 2.3 & 2.7 & 1.1 & 2.4 \\
Haynesina depressula & 2.0 & 4.0 & 0.0 & 4.0 & 0.0 & 2.1 \\
Nonionella turgida & 2.6 & 1.2 & 4.1 & 3.1 & 2.6 & 2.3 \\
Quinqueloculina seminulum & 4.3 & 7.7 & 1.0 & 10.9 & 1.3 & 0.7 \\
Textularia sagittula & 0.2 & 0.0 & 0.3 & 0.1 & 0.1 & 0.3 \\
Stainforthia fusiformis & 1.0 & 1.1 & 1.0 & 0.9 & 0.5 & 1.7 \\
FD & & & & & & \\
S & 10.0 & 0.2 & 19.9 & 8.2 & 16.2 & 5.7 \\
Infaunal (\%) & 9.7 & 6.0 & 13.4 & 10.1 & 9.1 & 9.9 \\
FAI & 95.4 & 92.3 & 98.5 & 88.8 & 98.6 & 98.9 \\
& 4.0 & 5.4 & 2.5 & 4.9 & 3.2 & 3.7 \\
\hline
\end{tabular}

genera, such as Ammonia, Aubignyna, Bolivina, Eggerelloides and Nonionella, as well as by a relatively low occurrence of epifaunal taxa belonging to the Quinqueloculina genus. The most abundant taxa were Ammonia parkinsoniana (46.3\%, on average), Ammonia tepida (13.4\%, on average) and Eggerelloides scaber (12.6\%, on average) (Table 2). Higher relative abundances of A. parkinsoniana, E. scaber, Haynesina depressula and Quinqueloculina seminulum were found in the stations close to the coast, whereas the opposite trend was highlighted for Aubignyna perlucida, Bolivina seminuda, Hopkinsina pacifica and Nonionella turgida. Lower relative abundances of A. parkinsoniana and E. scaber were recorded during the spring than in summer and autumn, while the spring also exhibited higher abundances of A. tepida, A. perlucida, Bolivina striatula, Buliminella elegantissima, $H$. pacifica, $H$. depressula and $Q$. seminulum. There was a marked increase in FD seawards, ranging from 0.1 (at several stations) to 75 (V4S) (Table 2 ). Meanwhile, higher FD values were documented during the summer, followed by spring and autumn. The foraminiferal assemblages were more diversified in the stations that were farthest from the seacoast, as documented by a clear seawards-increasing trend in $\mathrm{S}$, whereas no variations in $\mathrm{S}$ were noted in relation to the sampling seasons. On average, the infauna had slightly higher values seawards, while lower values were generally recorded in spring, followed by summer and autumn. Meanwhile, the average FAI values were higher at the stations closest to the seacoast and in spring (Table 2). 

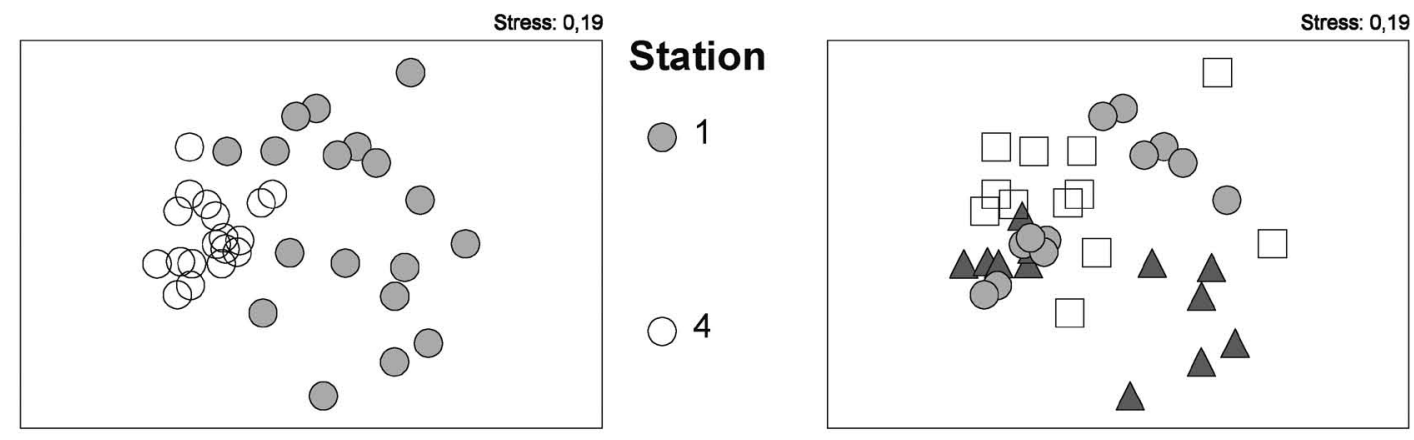

Season

Foraminifera
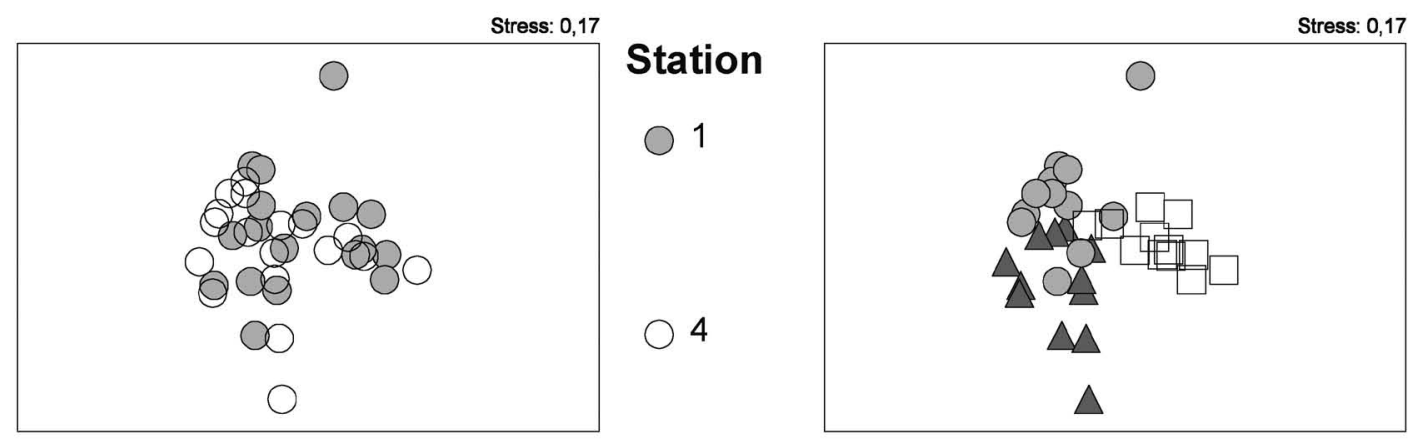

Season

$\triangle \mathrm{SP}$

$\triangle \mathrm{SP}$

s

A

\section{Meiofauna}
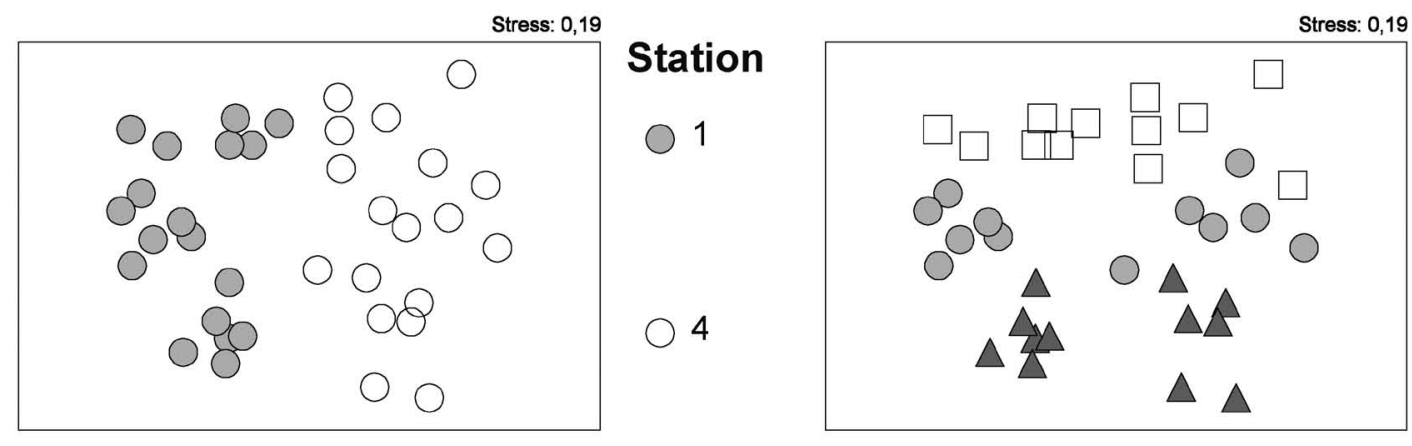

Season

$\triangle \mathrm{SP}$

$S$

A

\section{Macrofauna}

FIG. 2. - nMDS plot of foraminifera, meiofaunal and macrofaunal assemblages. The symbols represent the depth (a) or season (b) variations.

The variations in the foraminiferal assemblages exhibited a significant and major dissimilarity in the depth comparison (ANOSIM, $\mathrm{R}=0.75 ; \mathrm{p}=0.001$ ), while a lower seasonal difference was found by the ANOSIM $(\mathrm{R}=0.49 ; \mathrm{p}=0.001)$ and confirmed by the nMDS plot (Fig. 2). Highly positive correlation coefficients among the TOM and FD (0.82) and S (0.77) were also identified (Supplementary Material, Appendix 1).

\section{Meiofauna}

A total of 14 meiofaunal taxa were detected. The TMED ranged from $59.6 \pm 37.4$ to $1479.8 \pm 522$ ind.
$10 \mathrm{~cm}^{-2}$ (V4SP and M1S, respectively), with higher values in the summer (Table 3). The dominant taxon was the nematodes, with a mean density ranging from 1.7 (B1S) to 1272.5 (M1S) ind. $10 \mathrm{~cm}^{-2}$, which represented an average of $78 \%$ of the total meiofauna (range, $0-96 \%$ ). The next most abundant taxa were the polychaetes (on average 11\%; range, 1-56\%), platyhelminthes (on average 6\%; range, $0-94 \%$ ), copepods (on average $3 \%$; range, $0.1-18 \%$ ) and oligochaetes (on average $2 \%$; range, $0.2-9 \%$ ). Overall, the contribution of the remaining taxa was less than $1 \%$ and they were therefore cumulatively considered as 'Others'. There was significant, but low, dissimilarity in the depth com- 
TABLE 3. - Meiofaunal density (ind. $10 \mathrm{~cm}^{-2}$ ) along with meiofaunal parameters. SP, spring; S, summer; A, autumn; TMED, total meiofauna density.

\begin{tabular}{lcccccc}
\hline & Mean & Stns 1 & Stns 4 & SP & S & A \\
\hline Nematoda & 345.2 & 347.7 & 342.8 & 243.4 & 600.7 & 191.7 \\
Copepoda & 11.5 & 7.5 & 15.6 & 3.7 & 18.5 & 12.4 \\
Platyhelminthes & 27.3 & 44.8 & 9.9 & 5.9 & 73.1 & 3.0 \\
Gastrotricha & 0.5 & 0.7 & 0.2 & 1.3 & 0.1 & 0.0 \\
Ostracoda & 0.1 & 0.0 & 0.2 & 0.0 & 0.1 & 0.2 \\
Polychaeta & 47.1 & 68.5 & 25.8 & 13.3 & 57.7 & 70.4 \\
Oligochaeta & 8.6 & 9.8 & 7.3 & 6.5 & 14.1 & 5.1 \\
Nemertina & 0.4 & 0.4 & 0.3 & 0.5 & 0.3 & 0.3 \\
Kinorhyncha & 0.4 & 0.2 & 0.7 & 0.0 & 0.1 & 1.1 \\
Halacarida & 0.1 & 0.1 & 0.2 & 0.0 & 0.4 & 0.0 \\
Amphipoda & 0.9 & 0.2 & 1.5 & 0.7 & 1.7 & 0.1 \\
Anisopoda & 0.0 & 0.1 & 0.0 & 0.1 & 0.0 & 0.0 \\
Cumacea & 0.1 & 0.1 & 0.1 & 0.1 & 0.1 & 0.0 \\
Sipunculida & 0.1 & 0.2 & 0.0 & 0.2 & 0.0 & 0.0 \\
TMED & 442.3 & 480.1 & 404.5 & 275.9 & 766.9 & 284.2 \\
H'(ME) & 1.0 & 1.0 & 0.9 & 0.9 & 0.8 & 1.2 \\
J' (ME) & 0.4 & 0.4 & 0.4 & 0.3 & 0.3 & 0.5 \\
\hline
\end{tabular}

parison (ANOSIM, $\mathrm{R}=0.14 ; \mathrm{p}=0.022$ ) for the meiofaunal assemblage, which was confirmed by the nMDS plot (Fig. 2). In particular, the inshore-offshore differences were mainly due to the increase in nematodes, platyhelminthes, polychaetes and oligochaetes in the shallower stations, and the copepods and amphipods offshore (Table 3 ). In contrast, the seasonal variations were greater (ANOSIM, $\mathrm{R}=0.55 ; \mathrm{p}=0.001$ ): autumn was the period which was clearly different, and mainly showed the enhancement of polychaetes and the general decrement of all the other taxa (Table 3; Fig. 2). The correlation matrix highlighted a significantly positive coefficient (0.49) between sand and polychaetes and a negative coefficient with mud and TOM (0.51 and 0.42, respectively) (Supplementary Material, Appendix 1). The H' (ME) and J'(ME) indices revealed the highest values at station F4A (1.94 and 0.75, respectively), while the lowest values were recorded at station B4SP (0.31 and 0.11, respectively). Overall, T and $\mathrm{M}$ had the greatest diversity values, followed by $\mathrm{V}$ and $\mathrm{F}$. Moreover, the diversity values were very similar inshore and offshore, although they were greater at the shallower stations. A greater difference in these val- ues was, however, detectable across the seasons, with higher values in the autumn followed by spring and summer (Table 3 ).

\section{Macrofauna}

A total of 65 macrofaunal taxa were recorded (Table 4; Supplementary Material, Appendix 2). The TMAD revealed significant differences between both the depths (two-way crossed ANOSIM, $\mathrm{R}=0.84 ; \mathrm{p}=0.001$ ) and the seasons (two-way crossed ANOSIM, $\mathrm{R}=0.69$; $\mathrm{p}=0.001$ ), confirming the sub-divisions of the nMDS plot (Fig. 2). Density decreased with depth, while the highest values were recorded in summer. Although the highest values were observed at site $\mathrm{F}$ (on average $21500 \pm 11462$ vs. $13500 \pm 8142$ ind. $\mathrm{m}^{-2}$ for the other sites), no significant, clear differences between the sites were found.

On the whole, the assemblages were dominated by annelids $(68.5 \%)$, followed by mollusks $(21.7 \%)$, crustaceans $(8.4 \%)$, others $(1.1 \%)$ and echinoderms $(0.3 \%)$. This composition was similar across the sites, seasons and depths. The echinoderms did not occur at the inshore stations, while the crustaceans increased in importance with depth and during the spring. In general, the typical sandy biocoenosis species were more abundant (such as Chamelea gallina and Owenia fusiformis) or present only (Lentidium mediterraneum) at the shallowest stations. Roughly $70 \%$ of these organisms were suspension-feeders. Inversely, the muddy biocoenosis species (Harpinia crenulata) and organic enrichment indicator species (Abra alba, Abra prismatica, Corbula gibba and Nucula sulcata) either had higher densities or were present only at the deeper stations. Approximately $60 \%$ of these species were deposit-feeders (Table 4). The assemblages from the inshore stations were characterized by a higher TMAD than those offshore, while the Shannon H' index for macrofauna did not reveal any differences between the stations, but the Pielou J' index for macrofauna increased with depth. Diversity and the Pielou J' for macrofauna decreased from SP to A, but no clear pattern was observed be-

TABLE 4. - Macrofaunal density (ind. $\left.\mathrm{m}^{-2}\right)$ and biomass $\left(\mathrm{mg} \mathrm{m}^{-2}\right)$ along with macrofaunal parameters. SP, spring; S, summer; A, autumn; TMAD, total macrofauna density

\begin{tabular}{|c|c|c|c|c|c|c|c|c|c|c|c|c|}
\hline Macrofauna & Mean & Stns 1 & $\begin{array}{c}\text { Density } \\
\text { Stns } 4\end{array}$ & SP & $\mathrm{S}$ & A & Mean & Stns 1 & $\begin{array}{c}\text { Biomass } \\
\text { Stns } 4\end{array}$ & SP & $\mathrm{S}$ & A \\
\hline Cnidaria & 8.2 & 0.0 & 16.3 & 0.0 & 16.3 & 8.2 & 0.6 & 0.0 & 1.2 & 0.0 & 1.8 & 0.0 \\
\hline Nematoda & 13.6 & 21.8 & 5.4 & 24.5 & 16.3 & 0.0 & 0.0 & 0.0 & 0.0 & 0.0 & 0.0 & 0.0 \\
\hline Nemertea & 65.3 & 59.9 & 70.7 & 73.5 & 73.5 & 49.0 & 1.1 & 0.1 & 2.1 & 0.5 & 2.6 & 0.2 \\
\hline Priapula & 2.7 & 0.0 & 5.4 & 0.0 & 0.0 & 8.2 & 0.1 & 0.0 & 0.1 & 0.0 & 0.0 & 0.2 \\
\hline Sipunculida & 54.4 & 21.8 & 87.1 & 89.8 & 8.2 & 65.3 & 0.1 & 0.0 & 0.2 & 0.1 & 0.1 & 0.1 \\
\hline Platyhelminthes & 2.7 & 5.4 & 0.0 & 0.0 & 8.2 & 0.0 & 0.0 & 0.0 & 0.0 & 0.0 & 0.0 & 0.0 \\
\hline Mollusca & 3215.8 & 4489.1 & 1942.5 & 2016.0 & 3566.8 & 4064.6 & 92.4 & 17.4 & 167.5 & 145.9 & 101.8 & 29.6 \\
\hline Crustacea & 1237.9 & 1023.0 & 1452.8 & 2358.8 & 1248.8 & 106.1 & 1.0 & 1.7 & 0.4 & 0.3 & 1.8 & 0.9 \\
\hline Echinodermata & 40.8 & 0.0 & 81.6 & 24.5 & 57.1 & 40.8 & 6.7 & 2.5 & 11.0 & 0.2 & 16.1 & 3.9 \\
\hline Annelida & 10158.9 & 13891.6 & 6426.2 & 5501.1 & 12912.2 & 12063.3 & 14.5 & 14.8 & 14.1 & 9.2 & 16.2 & 18.0 \\
\hline TMAD & 14800.3 & 19512.5 & 10088.1 & 10088.1 & 17907.3 & 16405.5 & 116.5 & 36.4 & 196.6 & 156.1 & 140.5 & 52.9 \\
\hline $\mathrm{H}^{\prime}(\mathrm{MA})$ & 2.34 & 2.32 & 2.36 & 2.8 & 2.4 & 1.8 & - & - & - & - & - & - \\
\hline $\mathrm{J}^{\prime}(\mathrm{MA})$ & 0.78 & 0.72 & 0.84 & 0.82 & 0.75 & 0.78 & - & - & - & - & - & - \\
\hline
\end{tabular}




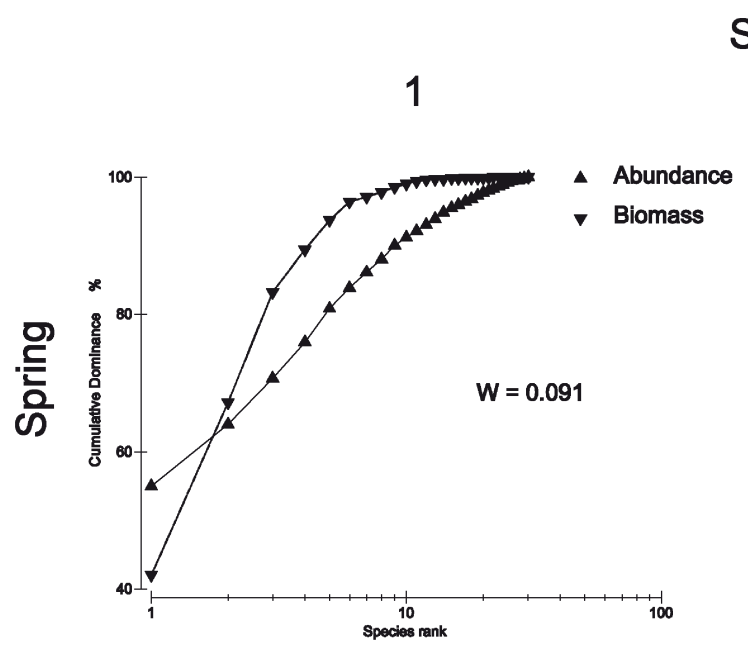

\section{STATION}
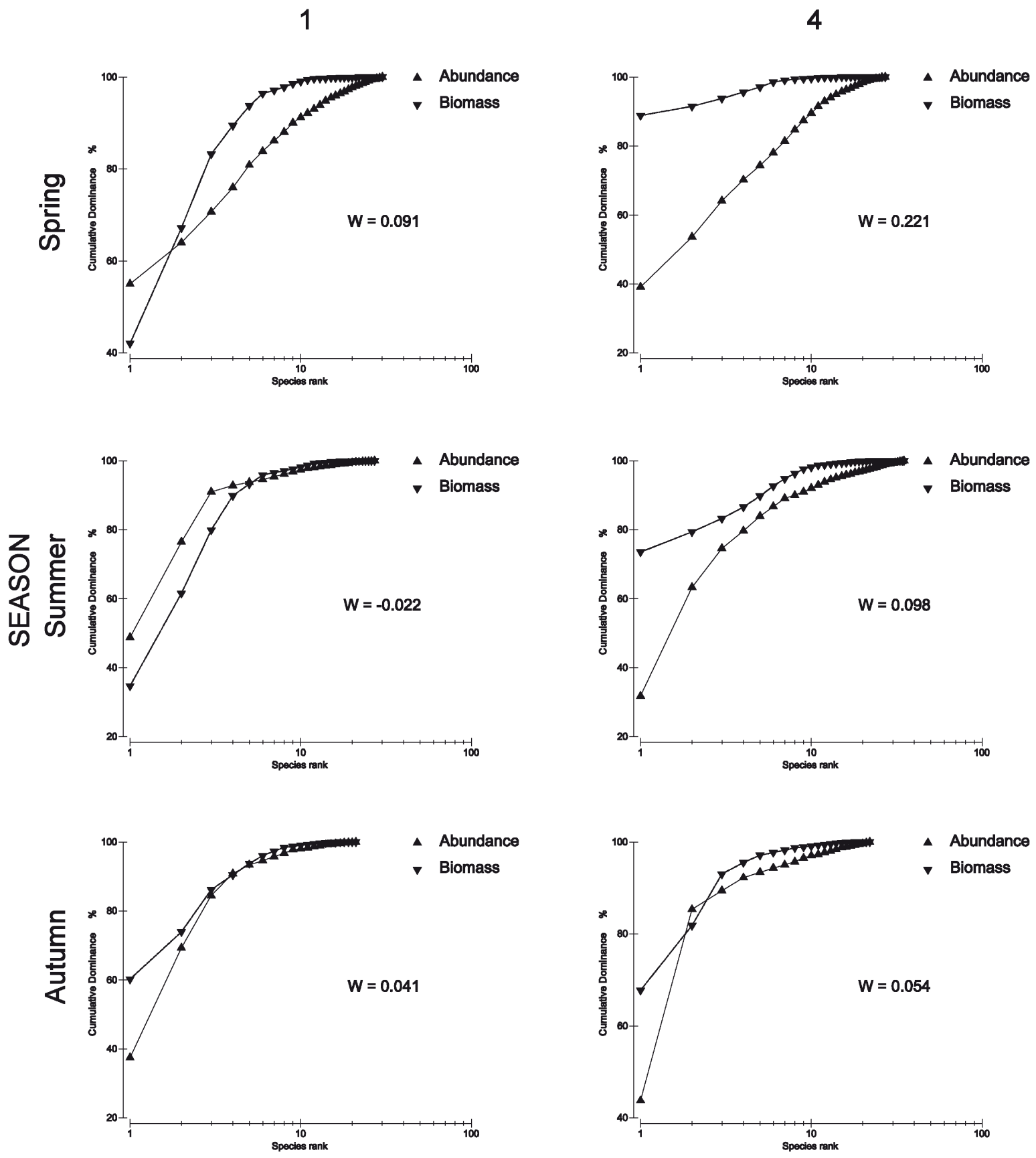

FIG. 3. - ABC curves applied to the macrofaunal assemblage data.

tween the sites. The highest values of the Pielou J' for macrofauna were observed at $\mathrm{T}$ and $\mathrm{M}$ (on average $0.84 \pm 0.61$ and $0.84 \pm 0.52$ respectively) and the lowest at $F$ (on average $0.72 \pm 0.20$ ). Diversity was higher at $\mathrm{T}$ (on average $2.75 \pm 0.61$ ) and lower at $\mathrm{V}$ (on average $1.96 \pm 0.70)$. The TMAB revealed an opposite pattern to the TMAD, and the values increased with depth (on average, $36.5 \pm 23.5$ and $196.6 \pm 307.5 \mathrm{mg} \mathrm{DW} \mathrm{m}^{-2}$ for stations 1 and 4 respectively) (Table 4). A clear decreasing pattern was observed from SP to A (on average, $156.1 \pm 329.7$ and $52.9 \pm 49.6 \mathrm{mg} \mathrm{DW} \mathrm{m}^{-2}$ for spring and autumn, respectively), while the highest biomass was found at FO (on average 365.8 \pm 506.0 and $66.7 \pm 64.2 \mathrm{mg} \mathrm{DW} \mathrm{m}^{-2}$ for the other sites). The greatest contributor to the TMAB was mollusks $(78 \%)$, followed by annelids (14\%), echinoderms $(5 \%)$, others $(2 \%)$ and crustaceans (1\%) (Table 4). The ABC method, averaged for season and station, 
revealed that the inshore stations in all seasons were moderately disturbed (W statistic close to 0 ), while the offshore stations were undisturbed during the spring and summer (W statistic values higher than 0 ), but moderately disturbed during the autumn (Fig. 3). The correlation matrix revealed that the TMAD was correlated positively with sand percentage $(0.51)$ and negatively with TOM $(-0.42)$. The TMAB, meanwhile, had significant and positive correlations with TOM (0.38) and mud percentage (0.41) (Supplementary material, Appendix 1).

\section{DISCUSSION}

The seasonal fluctuations of riverine inputs might affect environmental conditions and enhance the nutrient load along the coastal system, although the physico-chemical water conditions of the study area have been reported to be relatively stable (Frontalini et al. 2011). A clear distribution of sediment types was recognized in the study area. In particular, the sandy bottom dominated in the shallower stations, whereas the muddy-enriched sediments dominated at great depths. Similar results were obtained by Albertelli et al. (1999) and Semprucci et al. (2010a). These changes probably reflect the prevailing hydrodynamic conditions at the inner stations, where the re-suspension effects due to waves and currents are dominant. Moreover, the greater retention of sediment-bound organic matter and bacteria abundance in the finest sediments (Van Duyl and Kop 1994, Albertelli et al. 1999, Covazzi-Harriague et al. 2006) may induce a depletion in oxygen (Semprucci et al. 2010a). The nature of the organic matter of the study area was probably mainly refractory. Consequently, its trophic value was low for benthic organisms (Frontalini et al. 2011). Although no relevant changes in TOM were recorded in spring and summer, increasing organic matter contents were registered in autumn. These findings were probably related to a strong riverine input in autumn, as is also supported by the occurrence of suspended sediments (Colantoni et al. 2003). It is well known that the distribution of benthic communities varies in response to a complex array of variables, including sediment types, oxygen and trophic availability, salinity, temperature, hydrodynamic conditions and human influence.

The benthic foraminiferal assemblages were generally well-diversified, and were dominated by infaunal genera. These assemblages are typical of shallow, oligo-mesotrophic and moderately oxygenized environments. Most of the biocoenosis was constituted of herbivore feeding forms with a preference for mud and/or fine sand substrates. Ammonia, the most abundant taxon in the study area, was mainly represented by A. parkinsoniana and, albeit subordinated, the opportunistic species A. tepida. The former has been widely reported along the Italian coast between water depths of 10 and $20 \mathrm{~m}$, regardless of the substratum type and percentage of organic matter (Jorissen 1988). On the other hand, A. tepida is known for its great tolerance to all kinds of stress, both natural and anthropogenic (e.g. Alve 1995, Debenay et al. 2001, Armynot du Châtelet et al. 2004, Frontalini et al. 2009). The higher abundance of A. tepida found at the stations closest to the seacoast might be due to its ability to tolerate enhanced salinity variations (Almogi-Labin et al. 1995, Debenay et al. 2001). Bolivina seminuda, H. pacifica and $N$. turgida are characterized by a marked preference for muddy substrates and have been identified as highly opportunistic (Jorissen et al. 1992, Barmawidjaja et al. 1995, and reference therein). Nonionella turgida is reported to be a high motility taxon and able to migrate between oxic and anoxic layers, but it does not respond to fresh algal/diatom matter (Ernst et al. 2005). The same authors documented that $H$. pacifica exhibits high motility and responds by increasing its abundance under anoxia when a high input of labile organic matter is present. Bolivina, Bulimina, Buliminella, Stainforthia and Hopkinsina genera have been included within the low-oxygen foraminiferal assemblages (Bernhard and Sen Gupta 1999). According to Barmawidjaja et al. (1995), E. scaber can still be regarded, albeit to a lesser degree, as an opportunistic taxon, although it appears to be minimally affected by environmental changes (Ernst et al. 2005). Quinqueloculina seminulum, meanwhile, is considered to be an epifaunal taxon on firm substrates or soft sediments, and might be found in sand/mud substrates (Barmawidjaja et al. 1995). Clear, increasing diversity values were observed seawards, and this might reflect the more stable physico-chemical conditions of seawater and/or changes in substrate type. The diversity pattern did not demonstrate any seasonality, and these values remained quite constant over the three seasons. Diversity changes were markedly mirrored by a seawards increase in FD, which might be associated with mud fractions and their nutrient and detritus enrichments.

The number and composition of the meiofaunal taxa recorded in the study area are comparable with data reported for other Italian areas of high naturalistic value (Sandulli et al. 2010). The most abundant taxa, which are nematodes and polychaetes, are commonly considered to be tolerant groups (Vidakovic 1983; Pusceddu et al. 2007; Moreno et al. 2011). In particular, nematodes are well known to increase in number parallel to the fine fraction of the sediments (Steyaert et al. 1999, Vanaverbeke et al. 2002, Semprucci et al. 2010b, 2011), and are able to colonize even the deeper (suboxic) sediment layers (Heip et al. 1985, Mirto et al. 2004). In the study area, nematode abundance did not significantly differ between the inshore-offshore stations, and this is contrary to the trend observed by Semprucci et al. (2010a) in a neighbouring area. This observation, together with the enhancement of polychaetes, particularly inshore, supports the hypothesis of human disturbance effects in the coastal area of the Monte San Bartolo Natural Park. The abundance increase of the most sensitive taxa offshore (harpacticoid copepods, amphipods, ostracods) 
(Van Damme et al. 1984, Sundelin and Elmgren 1991, Fabroccini et al. 2005) is in accordance with this supposition. However, the statistical analysis has revealed small differences between the two depths in terms of the total community structure, thus underlining that the disturbance affecting the local coastal system can be regarded as moderate overall. Furthermore, the riverine inputs on this coast are the main source of disturbance (Semprucci et al. 2010a), but the highest meiofaunal diversity values were detected precisely at the stations facing the mouth of the Rivers Tavollo and Metauro, which evidently did not represent a great source of stress for the meiofauna during the period of this study. In contrast, the meiofaunal assemblages seemed to be highly and significantly affected by the seasonal variations, and there was a particularly clear difference in the autumn period. The general increase in the meiofaunal diversity values in the entire study area during this period corroborates the hypothesis of an irrelevant impact of river discharges on meiofauna. Indeed, the riverine inputs would be an advantage in contributing fresh trophic sources of high quality, the sedimentation of which can enrich the sea bottom, thus also becoming an important resource for the benthic domain (Semprucci et al. 2010a). This may explain the increase of copepods inshore during the autumn.

The macrofaunal assemblages were influenced by the sediment characteristics. Accordingly, the increase of TMAD at shallow stations is mainly due to the marked increase of polychaeta, particularly $O$. fusiformis. This taxon is quite tolerant and typical of the sandy substrate and shallow waters corresponding to the type of sediment found inshore (Simboura and Zenetos 2002). The macrofaunal abundance decreased with the increase of TOM contents in the sediments, and this might be linked to a lowering of the oxygenation state induced by the organic matter degradation. In fact, species indicators of organic enrichment, such as A. alba, A. prismatica, C. gibba and N. sulcata, had higher density values at the offshore stations. On the other hand, the structure of the assemblages changed with depth, as seen by the increasing Pielou J' values for macrofauna, and was related to the greater stability of the offshore environments and the decreasing influence of the riverine inputs. The same results were provided by the $\mathrm{ABC}$ curves, in which the inshore sites and only the offshore sites in autumn (when the riverine input was abundant) showed moderately disturbed conditions. Further confirmation was provided by the absence of echinoderms and the lower density of the amphipods, both of which are known as sensitive taxa, at the inshore stations (Blanchard et al. 2002, 2003, Covazzi-Harriague et al. 2007). From a functional point of view, the macrofaunal assemblages were linked to the sediment organic matter availability. Although the limited trophic value of the organic matter in this area was reported by Frontalini et al. (2011), the biomass increased with the increasing TOM contents. Indeed, the major reduction in macrofaunal density, and the slight decline in meiofaunal density observed at the offshore stations probably enhanced food availability. Moreover, this decrease in competition for the food source may have led to the weight increase of the macrofaunal organisms.

The spatial and temporal differences in the benthic communities were particularly evident in the macrofaunal assemblages due to fluctuations in the abundance and species composition of echinoderms, mollusks and crustaceans. The spatial distribution seems to be principally linked to the sediment features and food source. In fact, the greater abundances in the sandy bottoms and suspension-feeder species characterized the inshore and lower sedimentary organic content stations. In contrast, at the deepest stations, where the sediments were muddy and organically enriched, the species in the muddy bottoms and the deposit-feeders had elevated densities. The wide temporal fluctuations in abundance observed in some species could be related to either temperature, as in the case of the crustaceans, which were more abundant in the spring and summer, or to recruitment events, as in the case of L. mediterraneum, which settles its juveniles in the summer.

Good knowledge of the spatial and temporal distributions of coastal assemblages is a fundamental prerequisite for the conservation of a coastal zone within the framework of integrated management. The assemblages in the area are rather diversified, and generally minimally to moderately affected by anthropogenic activities. This finding is well documented by the entire benthic range. In particular, the foraminifera and macrofauna mainly seemed to be affected by spatial habitat variations, while the meiofauna were more affected by temporal fluctuations that are probably related to the trophic supply or biological cycles. The distinctive features of Monte San Bartolo Park suggest the potential vulnerability of this area and highlight the importance of defining and applying an appropriate integrated coastal zone management plan.

\section{ACKNOWLEDGEMENTS}

We warmly thank two anonymous reviewers for their helpful comments that have greatly improved the manuscript.

\section{REFERENCES}

Albertelli G., Covazzi-Harriague A., Danovaro R., Fabiano M., Fraschetti S. 1999. Differential responses of bacteria, meiofauna and macrofauna in a shelf area (Ligurian Sea, NW Mediterranean): role of food availability. J. Sea. Res. 42: 11-26.

Almogi-Labin A., Siman-Tov R., Rosenfeld A., Debard E. 1995. Occurrence and distribution of the foraminifer Ammonia beccarii tepida (Cushman) in water bodies, Recent and Quaternary, of the Dead Sea Rift, Israel. Mar. Micropaleontol. 26: 153-159.

Alve E. 1995. Benthic foraminifera response to estuarine pollution. A review. J. Foraminifer. Res. 25: 190-203.

Armynot du Chatelet E., Debenay J.P., Soulard R. 2004. Foraminiferal proxies for pollution monitoring in moderately polluted harbours. Environ. Pollut. 127: 27-40.

Artegiani A., Bregant D., Paschini E., Pinardi N., Raicich F. Russo 
A. 1997. The Adriatic Sea general circulation. Part II: baroclinic circulation structure. J. Phys. Oceanogr. 27: 1515- 1532.

Balsamo M., Albertelli G., Ceccherelli V.U., Coccioni R., Colangelo M.A., Curini-Galletti M., Danovaro R., D’Addabbo R., Leonardis C., Fabiano M. et al. 2010. Meiofauna of the Adriatic Sea: current state of knowledge and future perspective. Chem. Ecol. 26: 45-63.

Balsamo M., Penna A., Semprucci F., Coccioni R., Frontalini F., Scaravelli D., Manti A., Papa S. 2011. The coast of the S. Bartolo SCI (Marches, Italy) as a site in a network of Adriatic areas of conservation interest. Varstvo Narave, Supl.1, 173-174.

Barmawidjaja D.M., Van der Zwaan G.J., Jorissen F.J., Puskaric S. 1995. 150 years of eutrophication in the northern Adriatic Sea: evidence from a benthic foraminiferal record. Mar. Geol. 122: 367-384.

Bell S.S. 1980. Meiofauna-macrofauna interactions in a high salt marsh habitat. Ecol. Monogr. 50: 487-505.

Bernhard J.M., Sen Gupta B. 1999. Foraminifera of oxygen-depleted environments. In: Sen Gupta B. (ed.), Modern Foraminifera. Dordrecht, The Netherlands, Kluwer Academic Publishers, pp. 200-216.

Blanchard A.L., Feder H.M., Shaw D.G. 2002. Long-term investigation of benthic fauna and the influence of treated ballast water disposal in Port Valdez, Alaska. Mar. Pollut. Bull. 44: 367-382.

Blanchard A.L., Feder H.M., Shaw D.G. 2003. Variations in benthic fauna underneath an effluent mixing zone at a marine oil terminal in Port Valdez, Alaska. Mar. Pollut. Bull. 46: 1583-1589.

Buchanan J.B., Kain J.M. 1971. Measurement of the physical and chemical environment. In: Holme N.A., McIntyre A.D. (eds), Methods for the study of Marine Benthos. Oxford UK: Blackwell Scientific Publications. pp. 30-52.

Clarke K.R., Gorley R.N. 2001. PRIMER v5: User Manual/Tutorial. Plymouth: Primer-E Ltd.

Clarke K.R., Warwick R.M. 2001. Changes in marine communities: an approach to statistical analysis and interpretation. 2nd edition. Plymouth Marine Laboratory, Plymouth.

Coccioni R. (ed.). 2003. Verso la gestione integrata della costa del Monte San Bartolo: risultati di un progetto pilota. Quaderni del Centro di Geobiologia, Universita degli Studi di Urbino 'Carlo Bo', Arti Grafiche STIBU, Urbania.

Colantoni P., Mencucci D., Baldelli G. 2003. Idrologia e idraulica costiere processi litorali attuali e deposizione dei sedimenti. In: Coccioni R. (ed.), Verso la gestione integrata della costa del Monte San Bartolo: risultati di un progetto pilota. Quaderni del Centro di Geobiologia, Univ. Urbino. Urbania, pp. 15-39.

Colantoni P., Mencucci D., Nesci O. 2004. Coastal processes and cliff recession between Gabicce and Pesaro (northern Adriatic Sea): a case history. Geomorphology 62: 257-268.

Coll M., Piroddi C., Steenbeek J., Kaschner K., Ben Rais Lasram F., Aguzzi J., Ballesteros E., Bianchi C.N., Corbera J., Dailianis T., Danovaro R. et al. 2010. The Biodiversity of the Mediterranean Sea: Estimates, Patterns, and Threats. PLOS ONE. 5: 11842-11842.

Coull B.C., Bell S.S. 1979. Perspectives of marine meiofaunal ecology. In: R.J. Livingston (ed.) Ecological Processes in Coastal and Marine Systems. Plenum Publishing Corp., New York, pp. 189-216.

Coull B.C., Palmer M.A. 1984. Field experimentation in meiofaunal ecology. Hydrobiologia 118: 1-19.

Covazzi-Harriague A., Gaozza L., Montella A., Misic C. 2006. Benthic communities on a sandy Ligurian beach (NW Mediterranean). Hydrobiologia 571: 383-394.

Covazzi-Harriague A., Misic C., Petrillo M., Albertelli G. 2007. Stressors affecting the macrobenthic community in Rapallo harbour (Ligurian Sea, Italy). Sci. Mar. 71:705-714.

Danovaro R., Gambi C., Manini E., Fabiano M. 2000. Meiofauna response to a dynamic river plume front. Mar. Biol. 137: 359-370.

Danovaro R., Pusceddu A. 2007. Ecomanagement of biodiversity and ecosystem functioning in the Mediterranean Sea: concerns and strategies. Chem. Ecol. 23: 347-360.

Debenay J.P., Geslin E., Eichler B.B., Duleba W., Sylvestre F., Eichler P. 2001. Foraminiferal assemblages in a hypersaline lagoon Araruama (RJ) Brazil. J. Foraminifer. Res. 31: 133-151.

Ernst S.R., Bours R., Duijnstee I., van der Zwaan B. 2005. Experimental effects of an organic matter pulse and oxygen depletion on a benthic foraminifera shelf community. J. Foraminifer. Res. 35: 177-197.
Fabbrocini A., Guarino A., Scirocco T., Franchi M., D'adamo R. 2005. Integrated biomonitoring assessment of the Lesina Lagoon (Southern Adriatic Coast, Italy): preliminary results. Chem. Ecol. 21: 479-489.

Frontalini F., Coccioni R. 2008. Benthic foraminifera for heavy metal pollution monitoring: A case study from the central Adriatic Sea coast of Italy. Estuar. Coast. Shelf Sci. 76: 404-417.

Frontalini F., Coccioni R. 2011. Benthic foraminifera as bioindicators of pollution: A review of Italian research over the last three decades. Rev. Micropal. 54: 115-127.

Frontalini F., Buosi C., Da Pelo S., Coccioni R., Cherchi A., Bucci C. 2009. Benthic foraminifera as bio-indicators of trace element pollution in the heavily contaminated Santa Gilla lagoon (Cagliari, Italy). Mar. Pollut. Bull. 58: 858-877.

Frontalini F., Coccioni R., Bucci C. 2010. Benthic foraminiferal assemblages and trace element contents from the lagoons of Orbetello and Lesina. Environ. Monit. Assess. 170: 245-260.

Frontalini F., Semprucci F., Coccioni R., Balsamo M., Bittoni P., Covazzi-Harriague A. 2011. On the quantitative distribution and community structure of the meio and macrofaunal communities in the coastal area of the Central Adriatic Sea (Italy). Environ. Monit. Assess. 180: 325-344.

Gaudiano A., Pizzagalli C., Reggiani M.C., Banini L., Grassini P. 1994. Valutazione dello stato di inquinamento del fiume Foglia mediante l'uso di indicatori biologici. Amministrazione di Pesaro e Urbino. Fano.

Gunther C. 1996. Development of small mytilus beds and its effects on resident intertidal macrofauna. Mar. Ecol. 17: 117-130.

Heip C., Vincx M., Vranken G. 1985. The ecology of marine nematodes. Oceanogr. Mar. Biol. Annu. Rev. 23: 399-489.

Jorissen F.J. 1988. Benthic foraminifera from the Adriatic Sea: principles of phenotypic variation. Utr. Micropaleontol. Bull. 37: 1-174.

Jorissen F.J., Barmawidjaja D.M., Puskaric S., Van der Zwaan G.J. 1992. Vertical distribution of benthic foraminifera in the northern Adriatic Sea: the relation with the organic flux. Mar. Micropaleontol. 19: 131-146.

Lee M.R., Correa J.A., Castilla J.C. 2001. An assessment of the potential use of the nematode to copepod ratio in the monitoring of metals pollution. The Chanaral case. Mar. Pollut. Bull. 42: 696-701.

McIntyre A.D., Warwick R.M. 1984. Meiofauna techniques. In: Holme N.A., McIntyre A.D. (eds), Methods for the study of marine benthos. Oxford: Blackwell Scientific. pp. 217-244.

Mirto S., La Rosa T., Mocciaro G., Costa K., Sara G., Mazzola A. 2004. Meiofauna and benthic microbial biomass in a semienclosed Mediterranean marine system (Stagnone of Marsala, Italy). Chem. Ecol. 20: S387-S396.

Moodley L., Heip C., Middelburg J.J. 1998. Benthic activity in sediments of the northwestern Adriatic Sea: sediment oxygen consumption, macro- and meiofauna dynamics. J. Sea. Res. 40: 263-280.

Moreno M., Semprucci F., Vezzulli L., Balsamo M., Fabiano M., Albertelli G. 2011. The use of nematodes in assessing ecological quality status in the Mediterranean coastal ecosystems. Ecol. Ind. 11: 328-336.

Murray J.W. 2006. Ecology and Applications of Benthic Foraminifera. Cambridge University Press, New York.

Neira C., Mendoza G., Levin L. A., Zirino A., Delgadillo-Hinojosa F., Porrachia M., Deheyn D. D. 2011. Macrobenthic community response to copper in Shelter Island Yacht Basin, San Diego Bay, California. Mar. Pollut. Bull. 62: 701-717.

Pusceddu A., Gambi C., Manini E., Danovaro R. 2007. Trophic state, ecosystem efficiency and biodiversity of transitional aquatic ecosystems: analysis of environmental quality based on different benthic indicators. Chem. Ecol. 23: 505-515.

Sandulli R., De Leonardis C., Vanaverbeke J. 2010. Meiobenthic communities in the shallow subtidal of three Italian marine Protected Areas. Ital. J. Zool. 77: 186-196.

Sandulli R., De Leonardis C., Vincx M., Vanaverbeke J. 2011. Geographical and depth related patterns in nematode communities from some Italian Marine Protected Areas. Ital. J. Zool. 78: 505-516.

Semprucci F., Boi P., Manti A., Covazzi Harriague A., Rocchi M., Colantoni P., Papa S., Balsamo M. 2010a. Benthic communities along a littoral of the Central Adriatic Sea (Italy). Helgol. Mar. Res. 64: 101-115. 
Semprucci F., Colantoni P., Baldelli G., Rocchi M., Balsamo M. 2010b. The distribution of meiofauna on back-reef sandy platforms in the Maldives (Indian Ocean). Mar. Ecol. 31: 592-607.

Semprucci F., Colantoni P., Sbrocca C., Baldelli G., Rocchi, M. Balsamo M. 2011. Meiofauna in sandy back-reef platforms differently exposed to the monsoons in the Maldives (Indian Ocean). J. Mar. Syst. 87: 208-215.

Simboura N., Zenetos A. 2002. Benthic indicators to use in ecological quality classification of Mediterranean soft bottom marine ecosystems, including a new biotic index. Med. Mar. Sci. 3: 77-111.

Steyaert M., Garner N., Gansbeke D., Vincx M. 1999. Nematode communities from the North Sea: environmental controls on species diversity and vertical distribution within the sediment. J. Mar. Biol. Assoc. U. K. 79: 253-264.

Sundelin B., Elmgren R. 1991. Meiofauna of an experimental soft bottom ecosystem-effects of macrofauna and cadmium exposure. Mar. Ecol. Prog. Ser. 70: 245-255.

Van Damme D., Heip C., Willems A. 1984. Influence of pollution on the harpacticoid copepods of two North Sea estuaries. Hydrobiologia 112: 143-160.

Van Duyl F.C., Kop A.J. 1994. Bacterial production in North Sea sediments: clues to seasonal and spatial variations. Mar. Biol. 120: $323-337$.
Vanaverbeke J., Gheskiere T., Steyaert M., Vincx M. 2002. Nematode assemblages from subtidal sandbanks in the Southern Bight of the North Sea: effect of small sedimentological differences. J. Sea. Res. 48: 197-207.

Vidakovic J. 1983. The influence of row domestic sewage on density and distribution of meiofauna. Mar. Pollut. Bull. 14: 84-88.

Warwick R.M. 1986. A new method for detecting pollution effects on marine macrobenthic communities. Mar. Biol. 92: 557-562.

Zavatarelli M., Baretta J.W., Baretta-Bekker J.G., Pinardi N. 2000. The dynamics of the Adriatic Sea ecosystem. An idealized model study. Deep-Sea Res. I 47: 937-970.

Scient. ed.: R. Sardá.

Received May 2, 2012. Accepted January 18, 2013

Published online February 26, 2013.

\section{SUPPLEMENTARY MATERIAL}

The following Appendices are available through the web page http://www.icm.csic.es/scimar/supplm/sm03647SMA.pdf

APPENDix 1. - Pearson correlation matrix. Values in bold ( $\mathrm{p}<0.05$, 2-tailed test) and in italics and bold ( $\mathrm{p}<0.01$, two-tailed test).

APPENDIX 2. - List of macrofaunal species. 